\title{
Technological Environment and Some Selected Manufacturing Industry in Enugu State, Nigeria
}

\author{
Ikemefuna $^{1 *}$ and Abune $\mathrm{Abe}^{2}$
}

${ }^{1}$ Doctorial Research Candidate, Department of Business Administration, Nnamdi Azikiwe University, Awka, Nigeria

${ }^{2}$ Department of Business Administration, Kogi State University, Anyigba, Kogi State, Nigeria

\begin{abstract}
The study is based on reviewing the effect of technological environmental performance on the manufacturing industries aiming at some selected industries in Enugu State, Nigeria. The study revealed its problem statement as to effectively and efficiently train and adequately fund organizational equipment which will help in quick and better production. Primary and Secondary source of data were used as means of data collection. Ten (10) selected manufacturing industry were randomly selected across Enugu State while the Pearson Product Moment Correlation was used as the statistical tool for this study. The study was finally summarized with major findings which revealed that most manufacturing industries do not conduct training for their workers to meet up with this digital era. It is concluded that environment significantly affect the growth and performance of manufacturing industries in Enugu State. Based on this, the study recommends that staff training which enables better and efficient operation of machines and equipments, cost efficiency and investment in quality management are to be deliberately promoted in order to improve the performance of manufacturing industries.
\end{abstract}

Keywords: Technology; Environment; Manufacturing industries; Global business challenges

\section{Introduction}

Technological environment is associated with the external factors that impact on business operators. It also relates to the development of technology which affects business by way of new inventions of productions and other improvements in techniques to perform the business. The changing technological environment may pose threats or present opportunities [1].

The competitive nature of business environment and globalization has made it imperative for manufacturing organizations mostly to work hard towards identifying business strategies that will give them an edge over their competitor(s) [2].

Before an organization can begin its strategic formulation and implementation, it must scan the external environment to identify possible opportunities and threats and its internal environment for strengths and weaknesses. It is against the backdrop that environmental conditions and factors have the potentials to influence strategic decisions. Strategic planning is an organization's process of defining its strategy or direction and making decision on allocating its various business analytical techniques. What can be used in strategic planning include SWOT analysis (i.e. Strength, Weakness, Opportunities and Threats), PEST analysis (i.e. Political, Economic, Social and Technological), STEER analysis (i.e. Socio-Cultural, Technological, Economic, Ecological and Regulatory Factors) and EPISTEL (i.e. Environment, Political, Information, Social, Technological, Economic and Legal). Industrialization and economic development have been two of the critical interrelated and prominent objective pursued by many developing nations of the world [3].

One of the most pervasive factors in the environment is technology. Managers are generally concerned with two components of the technological environment; the process of innovation and the process of technology transfer. The process of innovation refers to their efforts in the basic sciences to develop new technologies, processes, methods and products [4]. While the process of technology transfer involves taking the new technology from the laboratory to the market, that is the transfer of science to useful products and applications $[5,6]$.

Theoretical and empirical investigations have emphasized the crucial role that technological innovation and entrepreneurship lay in fostering the development of today's industrialized nations. These types of investigation are now seen as crucial to the development of the third world, and they are accordingly recognized as important components of technology policy and indigenous socio-economic planning. The present emphasis on indigenous technical innovation and entrepreneurship stems from the failure of past attempts to stimulate Third World development by borrowing or transferring advanced technology from developed nations [7].

In most third world countries, governments are criticized for paying not more than lip service to the need for accelerated growth and for not 'harnessing the abilities of their own citizens for technological innovation and entrepreneurship'. Critics also lament that these countries depend too much on exogenous and often exploitative technology and they point out the inappropriate choices of technology made by many developing countries [8].

According to Inegbenebor, the desire of most developing countries, including Nigeria, is to have a self-reliant and resilient economy capable of generating an internally self-sustaining growth. For many decades, developing countries were exporters of raw materials and importers of finished goods from the colonial metropolis. Having recently gained political independence, these countries want to quickly transform their economies in order to achieve economic independence as well.

*Corresponding author: Ikemefuna, Doctorial Research Candidate, Department of Business Administration, Nnamdi Azikiwe University, Awka, Nigeria, Tel: +234 7064795433; E-mail: efunam2003@yahoo.com

Received June 24, 2015; Accepted July 10, 2015; Published July 17, 2015

Citation: Ikemefuna, Abe A (2015) Technological Environment and Some Selected Manufacturing Industry in Enugu State, Nigeria. J Glob Econ 3: 149. doi:10.4172/2375-4389.1000149

Copyright: ( $) 2015$ Ikemefuna, et al. This is an open-access article distributed under the terms of the Creative Commons Attribution License, which permits unrestricted use, distribution, and reproduction in any medium, provided the original author and source are credited. 
Generally, the word "Technology" is associated with the industrial arts, applied science engineering and with physical things [9]. It has been defined as the systematized practical knowledge, skills, methods, activities and artifacts by means of which man pushes back his limitations and extend his capability [10].

The technological environment in the manufacturing sector itself has changed dynamically from mechanized powered systems to the present day trend towards the application of advanced manufacturing technology which is seen in new products, machines, tools, materials and better mode of services. Among the benefits of technology are greater productivity, higher living standards, more leisure time and greater variety of products [11].

Technological impact on management practice is great. It is a vital element in planning both in the design of products and services and in their development, production and distribution [11].

\section{Statement of the problem}

The problem faced by Nigerian industries, especially in Enugu State, in their attempt to stay in line with the technological advancement in the global business environment include lack of fund to acquire a better technological equipment for production processes because of high cost of technology, inadequate power supply, lack of manpower and proper technical know-how and skills, inadequate training of workers on safety rules and regulations, workers' health as well as public health, poor waste management approach, technical limitations in handling material recycling, poor pollution control equipment, inadequate choice of technology and poor environmental management.

Thus, these technologies, if not well utilized, can cause havoc to the business environment. Through its effect on economic growth of the country and it could equally lead to environmental hazards. These hazards include but are not restricted to global warming, ozone depletion, loss of biodiversity, natural resources scarcity, air pollution, acid rain, toxic wastes and industrial accidents among others.

For effective and efficient use of modern technology, workers' training and adequate funding cannot be neglected.

\section{Objective of the Study}

The study's main objective is to determine the impact of technological environment on the performance of Nigerian manufacturing industries. Specifically, the study objective is based on reviewing the effect of technological performance on the manufacturing Industry in Nigeria.

\section{Research Question}

What has been the effect of technology on the performance of manufacturing industries in Enugu State?

\section{Hypothesis}

Ho: There are no significant effects of technological environment on the performance of Nigerian manufacturing industries.

H1: There are significant effects of technological environment on the performance of Nigerian manufacturing industries.

\section{Review of the Related Literature}

The importance of technology in the survival of the firms has long been established. Several authors have shown that the economic miracles experienced especially among the East Asian economics in the last half century tremendously benefited from policies that actively promoted firm level investments in technology in their manufacturing sectors.

Creations of industries are considered essential by most nations for the creation and propagation of wealth and for improving the living standard of its people. Their survival largely depends on a large extent on the environmental variables.

Every organization is affected by environmental factors. Environment can be defined as surroundings, especially the material and other affluences which affect the growth, development and existence of a living being or an organization [12].

Onuoha defines an environment as a set of condition and forces which surround and have direct influences on the manager and his organization. He broadly classified the environment into three (3) kinds. They are Internal, Task and General Environment [13]. This can be illustrated in a diagram-Figure 1.

The important elements in the environment of an organization include persons, physical resource and climate, economic and market conditions, attitude and laws [14]. According to [15], the environment provides three main things to the organizations;

i. Opportunities- because they help the organization to attain its objectives

ii. Threat- to those organizations that might engage in illegal acts, and

iii. Constraints such as antitrust laws, pollution-control regulations, price control measures, consumer protection, social approval or disapproval of business activities, and so on. In most cases, these environmental elements present challenges and problems for managers and organizations.

\section{Theoretical framework}

Giving that a manufacturing organization is an open system (i.e. is affected by its physical, commercial, legal, social and technological environment as well as its own environment, then the control subsystem

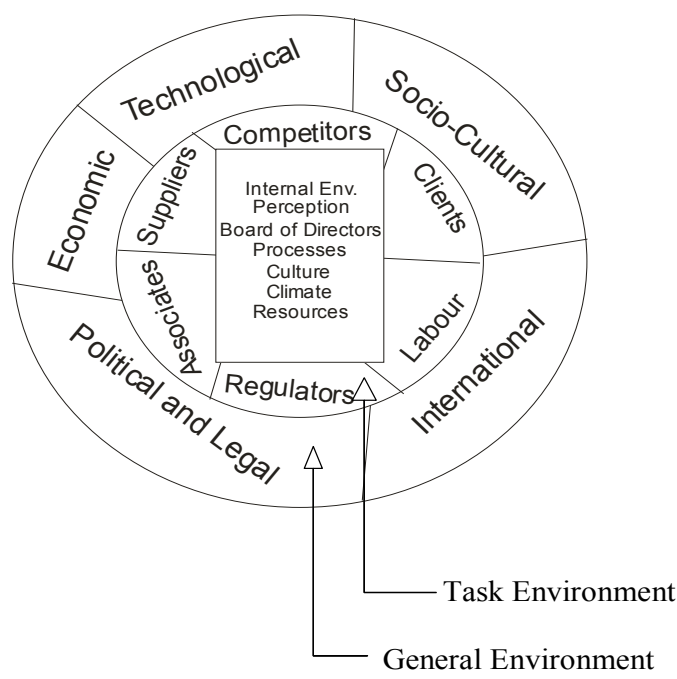

Source: Onuoha [13].

Figure 1: Organization and environment. 
must be able to remain in a stable state. this means that manufacturing technologies must be replaced as at when due and the new technology must be suitable, adaptable, easy to learn and maintain [1].

Onwuchekwa citing Ashby in his Law of Requisite Variety Theory, he stated that for any system to remain under control, the controller of that system must be able to absorb the entire range of inputs that may affect the system (i.e. the system or the control process must be at least as complex in its behavior as the system it is trying to control), organizations are neither self-sufficient nor self-contained. Further, they exchange resources with and are dependent upon the external environment defined as all elements outside an organization that are relevant to its operations. Organizations take inputs (raw materials, money, labor and energy) from the external environment, transform them (techniques) into products or services and then send them back as output to the external environment (Figure 2).

This by implication means that technological environment must be stable for the Nigerian manufacturing firms to thrive. Also, managers have to make the right choice of technology to match the existing environment [1]. Industrialists have to intelligently establish great manipulative skills for them to perform well frequently.

\section{Empirical literature}

The research work of Joan Woodward using 100 British manufacturing plants indicates that organization structure tends to vary with the types of technology employed. Thus, certain structures tend to be more successful with certain kinds of technology. Hence, the leadership and staffing of conglomerates tend to vary from those of sole proprietorship and other relatively small firms [16].

Lall in his study, he provides a theoretical links between investment in technology and performance and his analysis of the role of technology in international competitiveness. However, empirical findings on relationship between performance and technology have been mixed.

Elom EM argued on globalization and competitiveness, linking his view on selected manufacturing companies. In his opinion, globalization of markets and to uncertain business environment has increased the level of competitiveness which is putting increasingly greater pressure on organizations to increase their competitive advantage. He summarized that a country can only provide the enabling environment and the infrastructure that enables the firm to acquire and maintain competitive edge.

Adeeti J investigated on investment in technology by manufacturing firms in southwest Nigeria and how technology investment related factors affect the performance of manufacturing firms using data obtained from a survey of Nigerian firms in 2011 and found that investments in technology are dominated by imported technologies

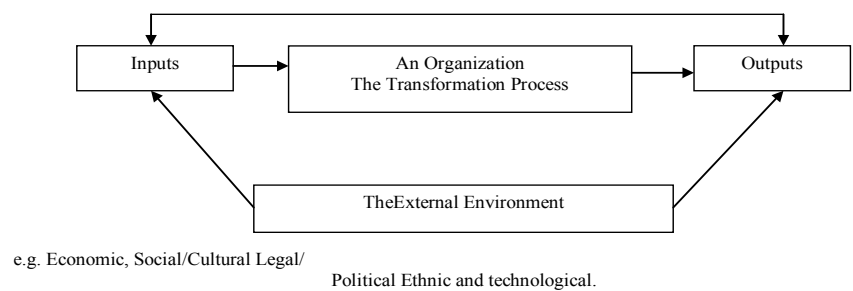

Source: Onuoha [13].

Figure 2: Systems view of an organization feedback. and technology investments are not directly targeted at export potentials and global competitiveness of firms.

Akpan PL [3] viewed his study as a nation's economic development through adequate industrialization. The study is empirical incline examining the relationship between industrialization and economic development with focus on Nigeria. The Ordinary Least Square (OLS) technique was adopted in line with diagnostic test for the model. Finally, the study advocates that a responsible government should embrace industrialization for meaningful economic growth so as to enhance export and discourage import.

Adesina OS [16] examines the positive and negative effects of globalization, focusing on its impact on science and technology on the Nigerian environment. In his arguments, he reviewed that globalization presents many opportunities; it also exposes developing countries like Nigeria to many new challenges. He finally suggests way by which the negative effects of globalization can be addressed.

Lal in a study of e-business and performance of small and mediumsized industries (SMIs) in India, he reported that the adoption of e-business technologies is an important factor in explaining the performance of Indian SMIs.

Having adequately reviewed the previous works above, the researcher observed that most researchers studied on globalization effect on technology, industrialization and economic development, playing down on suitability of local environmental technological issues, affordability, inadequate workers' training on technological environmental hazardous effects [17]. In view of this, the study intends to fill the overlapped gap by reviewing the influence of technological environmental factors on the performance of manufacturing industries aiming at some selected industries in Enugu State Nigeria.

\section{Technological Influence on the Manufacturing Industries in Nigeria}

Ezeilo FI [1] citing Adeoye, the following concepts is needed to help improve the manufacturing firms in Nigeria. They include the following.

Investment in ICT (E-business facilities): Investment in ICT is an important factor that has enabled the competitiveness of many successful economies in recent decades. However, while Nigerian manufacturing firms still lag behind in the use of ICT in the production process, Nigerian firms are beginning to employ ICT for operations management and other e-business activities Adeoti, Lal defines e-business to encompass the application of ICTs in all business processes such as office automating, production processes, coordination with other plants, customer relation management, supply chain management, and management of distribution network.

Investment in skills upgrading: For the purpose of this study, we conceive investment in skills upgrading to entail investment in training activities that enable better and efficient operation of machines and equipment. However, skills upgrading is generally reckoned as the outcome of learning mechanisms that enable firms improve their technological capability endowment. Shrivastava observed that skills upgrading fosters cross fertilization of knowledge, and thus enhances technological innovation and health friendly manufacturing processes.

Investment in technology hardware: This variable represents firm's implementation of a programme of reengineering that brings in new production equipment/machines or reengineering that improve existing production equipment/machines. Many Nigerian firms 
are known to use second hand machines/equipment due to capital constraints, and some even use production equipment that re obsolete. It is assumed that an immediate challenge that faces firms would be the necessity to embark on a reengineering programme that would replace obsolete or inefficient machines/equipment in order to significantly improve production performance.

Technological collaboration with foreign firm(s): Lal observed that technological collaboration between local and foreign firms can have positive impact on performance of firms. Technological collaboration in this respect can in the form of foreign direct investment in a subsidiary of a multinational firm or technology licensing, technical agreements, trademarks, etc.

\section{Methods}

The research survey design is adopted in this study. Both primary and secondary sources of data collections were employed.

In the course of carrying out this research, the researcher selected ten (10) manufacturing industries in Enugu State Nigeria, which will be critically analyzed using the Pearson product moment correlation.

The Table 1 below shows ten (10) different manufacturing industries across Enugu State Nigeria that was study.

The formula used for the correlation coefficient in this case is;

$$
\mathrm{r}=\frac{\Sigma \mathrm{n}(\mathrm{xy})-(\Sigma \mathrm{x})(\Sigma \mathrm{y})}{\sqrt{\mathrm{n}\left(\Sigma \mathrm{x}^{2}-(\Sigma \mathrm{x}) \mathrm{n}\left(\Sigma \mathrm{y}^{2}\right)-(\Sigma \mathrm{y})^{2}\right.}}
$$

Where: $\Sigma \mathrm{x}=$ the sum of the $\mathrm{x}$ values

$$
\begin{aligned}
& \Sigma y=\text { sum of the } y \text { values } \\
& \Sigma x^{2}=\text { sum of the squared } x \text { values } \\
& \Sigma y^{2}=\text { sum of the squared } y \text { values } \\
& \Sigma x y=\text { sum of the products of paired } x \text { and } y \text { values } \\
& n=\text { number of paired values }
\end{aligned}
$$

Using the above data which emanated from the effect of technological environmental factor on the performance of manufacturing industries in some selected industries in Enugu State Nigeria (Table 2).

Applying the above formula, one has;

$$
r=\frac{10(1,383)-(55)(198)}{\sqrt{10(385)-(55)^{2}[10(6,418)]-(198)^{2}}}
$$

\begin{tabular}{|c|c|}
\hline Type of Manufacturing Industries & $\begin{array}{c}\text { Number of Manufacturing Industries } \\
\text { Studied }\end{array}$ \\
\hline Aluminum & 8 \\
\hline Plastic & 4 \\
\hline Painting & 20 \\
\hline Furniture & 22 \\
\hline Shoe Making & 20 \\
\hline Polythene (Waterproof) & 5 \\
\hline Plumbing & 4 \\
\hline Sachet/Bottle Water & 32 \\
\hline Bakeries & 25 \\
\hline Block & 58 \\
\hline Total & $\mathbf{1 9 8}$ \\
\hline
\end{tabular}

Source: Field Survey, 2014

Table 1: Ten different manufacturing industries across Enugu State Nigeria.

\begin{tabular}{|c|c|c|c|c|}
\hline $\mathbf{x}$ & $\mathbf{y}$ & $\mathbf{x}^{\mathbf{2}}$ & $\mathbf{y}^{\mathbf{2}}$ & $\mathbf{x y}$ \\
\hline 1 & 8 & 1 & 64 & 8 \\
\hline 2 & 4 & 4 & 16 & 8 \\
\hline 3 & 20 & 9 & 400 & 60 \\
\hline 4 & 22 & 16 & 484 & 88 \\
\hline 5 & 20 & 25 & 400 & 100 \\
\hline 6 & 5 & 36 & 25 & 30 \\
\hline 7 & 4 & 49 & 16 & 28 \\
\hline 8 & 32 & 64 & 1024 & 256 \\
\hline 9 & 25 & 81 & 625 & 225 \\
\hline 55 & 58 & 100 & 3364 & 580 \\
\hline$\Sigma x=55$ & $\Sigma y=198$ & $\Sigma x^{2}=385$ & $\Sigma y^{2}=6,418$ & $\Sigma x y=1,383$ \\
\hline
\end{tabular}

Table 2: Effect of technological environmental factor on the performance of manufacturing industries in some selected industries in Enugu State Nigeria.

$$
\begin{aligned}
& r=\frac{13,830-10,890}{\sqrt{(3,850-3,025)(64,180-39,204)}} \\
& r=\frac{2,940}{\sqrt{825 \times 24,976}} \\
& r=\frac{2,940}{\sqrt{20,605,200}} \\
& r=\frac{2,940}{4,539.3} \\
& r=0.6477 \\
& d f=(n-2) \\
& =10-2=8 \\
& d f=8
\end{aligned}
$$

The critical value at $\mathrm{df}$ of $8=0.632$

\section{Decision rule}

The computed value is greater than its critical value $(0.6477>$ 0.632). Therefore, we shall reject the null hypothesis and accept the alternative hypothesis which posits that "there are significant effects of technological environment on the performance of manufacturing industries" in Enugu State Nigeria.

\section{Summary of Findings}

Based on the study's general objective which is to determine the impact of technology on the performance of Nigerian manufacturing industries in some selected manufacturing industries in Enugu State, the study revealed as follows from the result of data analysis.

Most Nigerian workers do not have innovation-supportive culture and the government is not doing enough in terms of incentives to boost the morale of manufacturers. This leads to difficulty in operation of the advanced manufacturing technology and high cost of maintenance when the machine breaks down.

Technological environment significantly affect the performance of manufacturing firm due to the fact that most manufacturers do not measure the acquired/imported and local technology in terms of adaptability, affordability, maintenance and waste of learning for maximum utilization. 
Most manufacturing industries do not conduct training for their workers because of lack of fund thereby exposing the workers and the public to industrial hazards.

Finally, the result however showed that where the technology is working properly, performance will increased.

\section{Conclusion}

The study investigates the impact of technological environment on the manufacturing industries in Nigeria, focusing on Enugu State. Data critically analyzed that technological environment significantly add value to the growth and performance of manufacturing industries. Attention is drawn on other variables that have influence on the technological environment of manufacturing industries to include funds, skills, industrial regulations, technological unsuitability to local environment, workers attitude towards technological innovation and government's efforts at encouraging manufacturing. It is on this ground that this study advocates for proper training of staff, easy access to fund, better choice of technology and better industrial policies for improved manufacturing business.

\section{Recommendations}

Based on the findings, the following suggestions are ought to carry out technological innovations which is aimed at improving business environment and performance.

Government should make favorable monetary policies that will encourage easy access to fund which will enable manufacturers to purchase better equipment for production. It is also of the view that government should also provide them with incentives in form of equipments, infrastructural facilities and financial resources to encourage production.

It is also of the view that technology should be made suitable and adaptable to the local environment, it should also ensure that it is affordable, easy to maintain and operate. This is to avoid high cost of maintenance and to ensure maximum utilization of the machine for proper performance.

Industrial policies should be reviewed to ensure reduction in pollution, waste recycling and industrial safety by the National Policy on Waste Management.

Finally, the study advocates that technological investment which is related to high level skills in manufacturing activities, staff training which enables better and efficient operation of machines and equipment, cost efficiency and investment in quality management are to be deliberately promoted in order to improve the performance of manufacturing industries.

\section{References}

1. Ezeilo FI (2014) Technological environment and the Nigerian manufacturing firms: Evidence from Selected Firms in Delta State.

2. Nwekpa KC, Elom EM (2012) Gaining cost competitive advantage in the manufacturing industry through the application of aggregate planning strategies: An illustration. Awka Journal of the Management Sciences 12 :45-59.

3. Akpan PL (2011) Periscoping industrialization and economic development of emerging economies: An empirical evidence from Nigeria. Awka: Global Journal of Management and Social Sciences.

4. Baldgride VJ, Burnham R (1975) Organizational Impact. Administrative Society

5. Ulterback JM (1974) Innovation in Industry a Diffusion of Technology. Science 183: $620-626$.

6. Gruber WH, Marguis DG (1971) Factors in the transfer of technology Cambridge Mass, MIT Press, UK

7. Adjebeng-Asem S (1995) Translating technical innovation into entrepreneurship in Nigeria: Social and policy implementation. Technology Policy and Practice in Nigeria, Otawa, Canada.

8. Oghene CK (2010) Entrepreneurial marketing as a key factor in the realization of Nigeria's Vision 2020. Nigerian Academy of Management Journal 4: 67-81.

9. Steiner GA (1975) Management and Society. New York.

10. Drucker PF (1970) Technology, management and society. Harvard Business Review Press, London.

11. Yalokwu PO (1999) Management concepts and techniques. Peak Publishers.

12. Ile NM (2000) Comparative and international management. Ochumba Printing and Publishing Company.

13. Onuoha BC (2008) Fundamentals of business and management in Nigeria Avan Global Publications.

14. Hicks HG, Gullett CR (1981) Management of organizations: A systems and human resources approach. McGraw-Hill.

15. Onuoha BC (2007) A handbook for successful management of organization Educational Books and Investment Limited Publishers.

16. Adesina OS (2012) The negative impact of globalization on Nigeria. International Journal of Humanities and Social Sciences 2: 193-201.

17. Obikeze DS (1986) Introductory statistics for the social sciences. Fourth Dimension Publishing Company Limited. 